\title{
Analisis Nilai Tambah dan Strategi Pengembangan Industri Keripi k Kentang Di PT Agro Lestari Merbabu Kecamatan Ngablak, Kabupaten Magelang
}

\section{Added Value Analysis and Strategy of Potato Chip Business Development at PT Agro Lestari Merbabu Ngablak District, Magelang Regency}

\author{
Dias Astuti ${ }^{1}$, Titik Ekowati ${ }^{2}$, Mukson ${ }^{3}$
}

Article Submitted: 09-11-2021

Article Accepted: 27-12-2021

Program Studi Agribisnis, Fakultas Peternakan dan Pertanian Universitas Diponegoro

Kampus Drh.R. Soeyono Koesoemowardojo, Tembalang, Semarang, 50275

Email: diasastuti1999@gmail.com

\begin{abstract}
Increasing business profits can be done through value added strategies and product development. The business development strategy is a long-term strategy for effective management by considering the strengths, weaknesses, opportunitie, and threats. The purpose of the study was to analyze the added value of potato chips products, to formulate internal and external factors that affect the potato chips business, and to formulate and determine the strategy for developing the potato chips business at PT Agro Lestari Merbabu. The research was conducted in March - April 2021, located in Magelang Regency. The research method used is a case study. Respondents amounted to 10 people consisting of internal parties and company stakeholders. The method of determining respondents using the purposive method. The research data were analyzed using descriptive analysis, added value, and SWOT analysis. Based on the results of the analysis, it can be seen that the Merbabu Potato Chips business produces an added value of IDR 20,533/kg and a valueadded ratio of 52.65\%. The potato chip business has main strengths in the form of an easy production process, the main weakness is that the company does not do much promotion, and there are 2 main opportunities in the form of regional conditions that support production activities and many tourist attractions as well as the main threat to slow market growth. The company's position in the IE matrix is in cell $V$ and it is better to hold and maintain. The priority strategy suggested for the Merbabu Potato Chips business is to market the product to tourist attractions at a relatively affordable and stable price.
\end{abstract}

Keywords: added value, bussiness, potato chips, strategy

\section{PENDAHULUAN}

Kabupaten Magelang merupakan salah satu kabupaten di Provinsi Jawa Tengah yang menjadi sentra industri penghasil produk tanaman pangan. Tanaman pangan merupakan tanaman yang bersumber dari hayati yang dapat maupun tidak dapat diolah serta masyarakat sering menjadikannya sebagai bahan makanan utama. Tanaman pangan memiliki potensi yang tinggi untuk terus dikembangkan karena memiliki nilai ekonomis dan nilai tambah lebih tinggi dibandingkan dengan komoditas lainnya (Nurdina et al., 2021). Tanaman pangan dapat dikreasikan dan diolah menjadi berbagi macam produk olahan, mulai dari produk makanan kering maupun basah. Produk olahan tanaman pangan berpeluang untuk dikembangkan mengingat semakin meningkatnya minat konsumen. Hal ini terjadi karena rasa produknya yang cenderung enak, mudah untuk ditemukan, harganya yang relatif murah dan sering dijadikan buah tangan. Produk olahan tanaman pangan berpotensi terus dikembangkan karena dapat mendukung upaya pemanfaatan potensi lokal, pemberdayaan ekonomi masyarakat sekitar, peningkatan nilai tambah produk serta pemenuhan kebutuhan konsumen. Ekonomi masyarakat sekitar akan terangkat seiring terus meningkatnya permintaan konsumen terhadap produk olahan. Komoditas pada tanaman pangan terdiri dari padi, jagung, kentang, kacang tanah, kacang hijau, ubi dan sorgum.

Tanaman kentang dapat tumbuh dengan baik apabila kondisi iklim mendukung dan dirawat dengan baik sehingga dapat meningkatkan daya jualnya. Kentang cukup populer dengan diolah menjadi berbagai menu seperti potato chips/keripik kentang, donat kentang, french fries, kue lumpur, kroket, dan berbagai macam olahan lainnya. Konsumsi kentang di Indonesia cukup tinggi yaitu konsumsi pada Tahun 2012 sekitar 1,460 kg/kapita/tahun Tahun 2013 sebesar 1,480 $\mathrm{kg} / \mathrm{kapita} / \mathrm{tahun}$ dan di Tahun 2014 sama dengan tahun sebelumnya yaitu $1,480 \mathrm{~kg} / \mathrm{kapita} / \mathrm{tahun}$ (BPS, 2016).

Pengolahan merupakan penanganan pasca panen dari suatu komoditas dengan tujuan meningkatkan daya simpannya maupun meningkatkan nilai ekonomis komoditas tersebut. Kentang diproduksi melalui serangkaian proses pengolahan agar mampu menghasilkan keripik kentang yang berkualitas. Proses pengolahan 
kentang menjadi keripik kentang dapat meningkatkan pendapatan produsen karena adanya nilai tambah yang dihasilkan setiap produksinya. Nilai tambah merupakan nilai suatu komoditas yang bertambah tinggi dikarenakan adanya input fungsional yaitu dapat berupa proses pengubahan bentuk (form utility), pemindahan tempat (place utility) serta proses penyimpanan (time utility). Peningkatan nilai tambah yang menguntungkan produsen ini memerlukan pemilihan strategi pengembangan yang tepat agar produk dapat terjaga kualitasnya. Strategi pengembangan usaha merupakan strategi berupa rencana jangka panjang untuk manajemen efektif dengan melihat kesempatan dan ancaman lingkungan, serta mempertimbangkan kekuatan dan kelemahan (Indariawati, 2011). Perusahaan yang dapat menjamin kualitas produk yang ditawarkan dan menerapkan strategi pengembangan yang tepat akan meningkatkan kuantitas produk yang terjual.

PT Agro Lestari Merbabu merupakan perusahaan yang bergerak dibidang pertanian dan menjual produk pertanian baik dalam bentuk mentah maupun olahan. Produk PT Agro Lestari Merbabu berupa kentang, cabai, kubis, seledri, daun bawang, sapi potong, bibit kentang dan keripik kentang. Perusahaan mampu menghasilkan produk kentang yang berkualitas unggul karena didukung oleh lokasi yang strategis dan kondisi iklim seperti suhu, tanah subur serta curahan hujan yang tidak terlalu tinggi. PT Agro Lestari Merbabu ini menjalankan usaha tepatnya di Desa Sumberejo, Kecamatan Ngablak, Kabupaten Magelang dan melakukan kegiatan budidaya tanaman pangan pada lahan sekitar Kecamatan Ngablak. Produk perusahaan ini dipasarkan ke wilayah Kota Semarang, Kabupaten Pekalongan, Kabupaten Magelang dan Kota Solo.

Harga kentang mentah dipasaran adalah Rp. $8.000 / \mathrm{kg}$ sedangkan keripik kentang dihargai Rp. $130.000 / \mathrm{kg}$. Hal ini tentunya menjadi usaha yang cukup menjanjikan jika dapat terus dikembangkan. Akan tetapi, usaha keripik kentang pada bulan Oktober 2020 mengalami penurunan volume produksi. PT Agro Lestari Merbabu melakukan produksi keripik setiap 3 hari sekali dengan berat kentang mentah rata-rata yang awalnya sebanyak $200 \mathrm{~kg} / \mathrm{sekali}$ produksi menjadi $100 \mathrm{~kg} / \mathrm{sekali}$ produksi. Penurunan volume produksi ini berimbas pada penurunan pendapatan usaha keripik kentang dan pelaksanaan pengembangan usaha yang belum maksimal. Perusahaan membutuhkan perencanaan yang matang, perumusan strategi, kemampuan membaca pasar dan pengaplikasian yang tepat mendorong terjadinya peningkatan keberhasilan strategi yang diterapkan dan berpengaruh pada peningkatan pendapatan produk keripik kentang.

Penelitian terkait nilai tambah dan strategi pengembangan usaha di PT Agro Lestari Merbabu bertujuan untuk 1) Menganalisis nilai tambah produk keripik kentang di PT Agro Lestari Merbabu, 2) Menganalisis strategi pengembangan usaha meliputi faktor internal dan eksternal yang berpengaruh terhadap usaha keripik kentang di PT Agro Lestari Merbabu, dan 3) Merumuskan dan menentukan strategi pengembangan usaha produk keripik kentang PT Agro Lestari Merbabu.

\section{BAHAN DAN METODE}

\section{Metode Penelitian}

Metode yang digunakan dalam penelitian ini adalah metode studi kasus. Metode pengumpulan data penelitian dilakukan dengan cara wawancara dan dokumentasi. Penelitian dilaksanakan pada bulan Maret sampai April 2021 di PT Agro Letari Merbabu. Penentuan lokasi penelitian menggunakan teknik purposive. Penentuan responden dalam penelitian ini menggunakan metode nonprobability sampling purposive dengan responden sebanyak 10 orang. Menurut Sugiyono (2018) metode nonprobability sampling purposive adalah teknik penentuan dan pengambilan sampel yang tidak memberikan peluang yang sama bagi setiap responden dan melakukan pertimbangan berupa kriteria tertentu. Kriteria pihak yang dapat dijadikan responden adalah orang yang dianggap memahami kondisi perusahaan dalam hal ini peneliti mengganggap bahwa pemilik perusahaan, tenaga kerja perusahaan dan stakeholder perusahaan dapat memberikan informasi terkait permasalahan yang diteliti.

\section{Analisis Data}

Metode analisis yang digunakan adalah analisis nilai tambah, analisis SWOT (Strenghts Weakness Opportunity Threaths), analisis deskriptif dan analisis strategi kemudian dibahas dengan melakukan studi literatur. Menganalisis nilai tambah produk keripik kentang di PT Agro Lestari Merbabu menggunakan analisis nilai tambah. Menganalisis pengembangan usaha yang meliputi faktor internal dan eksternal yang berpengaruh terhadap usaha keripik kentang dengan menggunakan matriks IFE dan EFE, serta analisis matriks IE untuk mengetahui posisi perusahaan. Perumusan alternatif strategi dilanjutkan dengan menggunakan analisis SWOT dan analisis deskriptif. Strategi pengembangan usaha produk keripik kentang PT Agro Lestari Merbabu diperoleh dengan menggunakan analisis strategi matriks QSP. Matriks QSP digunakan untuk mengevaluasi strategi secara obyektif berdasarkan faktor internaleksternal yang telah diidentifikasi pada tahap sebelumnya (Wardani dan Khoirudin, 2015).

\section{Analisis Nilai Tambah}

Nilai tambah yang diperoleh suatu perusahaan dianalisi menggunakan analisis nilai tambah metode Hayami. Pengukuran nilai tambah dilihat dari hasil perhitungan nilai tambah dan rasio 
nilai tambah yang dihasilkan (Ayesha et al., 2020). Prosedur perhitungan nilai tambah metode Hayami dapat dilihat pada Tabel 1.

Tabel 1. Perhitungan Nilai Tambah

\begin{tabular}{|c|c|c|}
\hline Variabel & Nilai & Notasi \\
\hline Output (kg) & & $\mathrm{A}$ \\
\hline Bahan Baku (kg) & & B \\
\hline Tenaga Kerja (HOK) & & $\mathrm{C}$ \\
\hline Faktor Konversi & & $\mathrm{D}=\mathrm{A} / \mathrm{B}$ \\
\hline $\begin{array}{l}\text { Koefisien Tenaga Kerja } \\
(\mathrm{HOK} / \mathrm{kg})\end{array}$ & & $\mathrm{E}=\mathrm{C} / \mathrm{B}$ \\
\hline Harga Output (Rp/kg) & & $\mathrm{F}$ \\
\hline Upah Tenaga Kerja (Rp/HOK) & & G \\
\hline Harga Bahan Baku (Rp/kg) & & $\mathrm{H}$ \\
\hline Sumbangan Input Lain $(\mathrm{Rp} / \mathrm{kg})$ & & I \\
\hline Nilai Output (Rp) & & $\mathrm{J}=\mathrm{D} \times \mathrm{F}$ \\
\hline Nilai Tambah $(\mathrm{Rp} / \mathrm{kg})$ & & $\mathrm{K}=\mathrm{J}-\mathrm{H}-\mathrm{I}$ \\
\hline Rasio Nilai Tambah (\%) & & $\begin{array}{l}\mathrm{L}=(\mathrm{K} / \mathrm{J}) \mathrm{x} \\
100 \%\end{array}$ \\
\hline $\begin{array}{l}\text { Pendapatan Tenaga Kerja } \\
(\mathrm{Rp} / \mathrm{kg})\end{array}$ & & $\mathrm{M}=\mathrm{E} \times \mathrm{G}$ \\
\hline Bagian Tenaga Kerja (\%) & & $\begin{array}{l}\mathrm{N} \\
=(\mathrm{M} / \mathrm{K}) \times 100 \%\end{array}$ \\
\hline Keuntungan $(\mathrm{Rp} / \mathrm{kg})$ & & $\mathrm{O}=\mathrm{K}-\mathrm{M}$ \\
\hline Tingkat Keuntungan (\%) & & $\begin{array}{l}\mathrm{P}=(\mathrm{O} / \mathrm{K}) \\
\mathrm{x} 100 \%\end{array}$ \\
\hline
\end{tabular}

Sumber : Hayami et al. (1987)

Nilai tambah dapat dihitung dengan rumus :

Added value $=$ nilai output - harga input bahan baku - sumbangan input lain

Keterangan :

Added value

Nilai output

dihasilkan $(\mathrm{Rp} / \mathrm{kg})$

$=$ nilai tambah $(\mathrm{Rp} / \mathrm{kg})$

$=$ nilai output produk yang

Sumbangan input lain = biaya untuk membeli bahan tambahan $(\mathrm{Rp} / \mathrm{kg})$

Kriteria penilaian pengembangan perusahaan yang digunakan diambil hasil perhitungan nilai tambah. Perusahaan dikatakan telah memberikan nilai tambah apabila diperoleh angka nilai tambah > 0 dan perusahaan dikatakan tidak memberikan nilai tambah ketika angka nilai tambah berada di angka $<0$ (Salsabila et al., 2019).

Kategori perusahaan dideteksi dengan melihat angka rasio nilai tambah produk tersebut. Perhitungan rasio nilai tambah dapat menggunakan rumus :

Rasio added value $=\frac{\text { Added value }}{\text { Nillai output }} \times 100 \%$

(Elvia, 2016)

Keterangan :

Rasio added value $=$ rasio nilai tambah $(\%)$

Nilai tambah suatu perusahaan dikategorikan rendah jika nilai rasio nilai tambahnya $<15 \%$, dikategorikan sedang jika nilainya berada di angka kisaran $15-40 \%$ dan dikategorikan tinggi jika nilainya > 40\% (Mubarok et al., 2015).

\section{Analisis SWOT}

Analisis SWOT dan analisis strategi teknik matriks QSP digunakan secara berkelanjutan. Penentuan strategi pengembangan usaha melalui 3 tahapan yaitu tahap pemasukan (input stage), tahap pencocokan (matching stage) dan tahap keputusan akhir (Prasnowo et al., 2017). Tahapan ini saling berkaitan antar satu dengan yang lain.

Tahap pemasukan berisi hasil perkalian bobot dan rating pada matriks Internal Factor Evaluation (IFE) dan Eksternal Factor Evaluation (EFE). Matriks IFE berisi hasil wawancara kepada responden berupa bobot dan rating faktor-faktor yang mempengaruhi strategi internal seperti kekuatan dan kelemahan yang dihadapi perusahaan (Sakina dan Tangkesalu, 2018). Matriks EFE berisi hasil wawancara berupa bobot dan rating faktorfaktor yang mempengaruhi penentuan strategi eksternal seperti peluang dan ancaman perusahaan.

Tahap pencocokan berisi matriks Internal Eksternal (IE) dan matriks SWOT. Matriks IE berfungsi untuk mengetahui posisi perusahaan dalam matriks IE dan matriks ini terdiri dari dua dimensi, yaitu total skor matriks IFE pa da sumbu $X$ dan matriks EFE pada sumbu Y. Matriks IE dikelompokkan menjadi tiga strategi utama yaitu :

1) Grow and Build (tumbuh dan bina) berada dalam sel I, II atau IV. Strategi yang cocok adalah intensif (penetrasi pasar, pengembangan pasar, dan pengembangan produk).

2) Hold and Maintain (pertahankan dan pelihara) mencangkup sel III, V, atau sel VII. Strategi umum yang dipakai adalah penetrasi pasar, pengembangan produk dan pengembangan pasar.

3) Harvest and Devest (panen atau divestasi) mencangkup sel VI, VIII atau IX. Strategi yang dipakai adalah divestasi, strategi diversifikasi konglomerat dan strategi likuidasi.

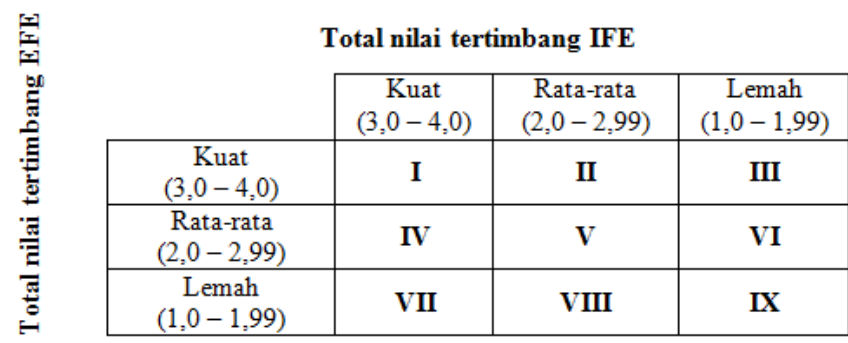

Ilustrasi 1. Matriks IE

Matriks SWOT berupa penentuan strategi yang ditempuh berdasarkan logika dengan memaksimalkan kekuatan dan peluang yang dimiliki namun secara bersamaan dapat meminimalkan kelemahan dan ancaman perusahaan. Matriks SWOT dirumuskan berdasarkan pertemuan masing-masing indikator 


\begin{tabular}{|l|c|c|}
\hline Eksternal & $\begin{array}{c}\text { Kekuatan } \\
\text { (Strenght) }\end{array}$ & $\begin{array}{c}\text { Kelemahan } \\
\text { (Weakness) }\end{array}$ \\
\hline $\begin{array}{l}\text { Peluang } \\
\text { (Opportunity) }\end{array}$ & $\begin{array}{c}\text { Strategi SO } \\
\text { (Strength- } \\
\text { Opportunity) }\end{array}$ & $\begin{array}{c}\text { Strategi WO } \\
\text { (Weakness- } \\
\text { Opportunity) }\end{array}$ \\
\hline $\begin{array}{l}\text { Ancaman } \\
\text { (Threats) }\end{array}$ & $\begin{array}{c}\text { Strategi ST } \\
\text { (Strength- } \\
\text { Threats) }\end{array}$ & $\begin{array}{c}\text { Strategi WT } \\
\text { (Weakness- } \\
\text { Threats) }\end{array}$ \\
\hline
\end{tabular}

pada SWOT dan akan disesuikan dengan kebutuhan perusahaan.

Ilustrasi 2. Matriks SWOT

\begin{abstract}
Analisis Strategi
Analisis strategi berisi tahap lanjutan yaitu tahap keputusan akhir. Tahap ini berisi matriks QSP yang digunakan untuk mengevaluasi strategi secara obyektif berdasarkan faktor internal dan faktor eksternal yang telah diidentifikasi pada tahapan sebelumnya (Wardani dan Khoirudin, 2015). Pembuatan matriks QSP didasarkan pada hasil evaluasi pada faktor internal maupun eksternal yang mempengaruhi strategi pengembangan perusahaan. Alternatif strategi yang digunakan dipilih berdasarkan nilai TAS yang terbesar. Strategi ini nanti akan direkomendasikan ke perusahaan ini melakukan kemitraan dengan petani pemilik lahan berupa kesepakatan terkait harga
\end{abstract}

Tabel 2. Matriks QSP

Faktor-Faktor Kunci

\begin{tabular}{cccccc}
\multirow{2}{*}{ Bobot } & S 1* & S 2 & S 3 & S 4 & S 5 \\
\cline { 2 - 5 } & AS** & AS & AS & AS & AS
\end{tabular}

Perusahaan mengelola keuangan usaha dengan baik

Harga yang ditawarkan terjangkau

Perusahaan melakukan kegiatan pencatatan secara rinci

Perusahaan mempunyai modal sendiri yang memadai

Hubungan pimpinan dan karyawan yang baik

Rasa produk yang enak

Perusahaan mempunyai bahan baku utama produksi sendiri

Peralatan sudah tersedia

Proses produksi mudah dilakukan

Harga produk stabil

Keterbatasan tenaga kerja produksi

PT Agro Lestari Merbabu belum lama berdiri

Pembagian kerja karyawan belum terstruktur

Teknologi yang digunakan masih sederhana

Perusahaan tidak banyak melakukan promosi

Penjualan produk tidak berkala

Kemasan produk kurang lengkap informasinya

Manajemen perusahaan belum terkoordinasi baik

Produk belum dipasarkan ke luar wilayah perusahaan

Sistem penjualan perusahaan pre order

Merk perusahaan sudah dikenal masyarakat

Pengiriman barang tepat waktu

Komunikasi dengan klien maupun konsumen berjalan baik

Penambahan tenaga kerja memungkinkan

Merk perusahaan sudah dikenal masyarakat

Pengiriman barang tepat waktu

Komunikasi dengan klien maupun konsumen berjalan baik

Penambahan tenaga kerja memungkinkan

Kepercayaan konsumen terhadap produk

Budaya membeli oleh-oleh 
Tabel 2. (Lanjutan)

\begin{tabular}{|c|c|c|c|c|c|c|}
\hline \multirow{2}{*}{ Faktor-Faktor Kunci } & \multirow{2}{*}{ Bobot } & $\mathrm{S} 1 *$ & $\mathrm{~S} 2$ & S 3 & S 4 & S 5 \\
\hline & & $\mathrm{AS} * *$ & AS & AS & AS & $\mathrm{AS}$ \\
\hline \multicolumn{7}{|l|}{ Kondisi wilayah mendukung kegiatan produksi } \\
\hline \multicolumn{7}{|l|}{ Semakin berkembangannya teknologi (internet) } \\
\hline \multicolumn{7}{|l|}{ Banyak tempat wisata disekitar lokasi produksi } \\
\hline \multicolumn{7}{|l|}{ Anggapan masyarakat bahwa produk harganya murah dan berkualitas } \\
\hline \multicolumn{7}{|l|}{ Persaingan produk serupa } \\
\hline \multicolumn{7}{|l|}{ Upah tenaga kerja yang sedikit } \\
\hline \multicolumn{7}{|l|}{ Kenaikan harga bahan baku pendukung } \\
\hline \multicolumn{7}{|l|}{ Pesaing lebih luas jangkauannya } \\
\hline \multicolumn{7}{|l|}{ Pertumbuhan pasar yang lambat } \\
\hline \multicolumn{7}{|l|}{ Kondisi dan situasi lingkungan (misal Pandemi Covid 19) } \\
\hline \multicolumn{7}{|l|}{ Pelanggan yang peka terhadap harga barang pesaing } \\
\hline \multicolumn{7}{|l|}{ Tenaga kerja yang kurang profesional } \\
\hline \multicolumn{7}{|l|}{ Kurangnya bimbingan teknis dan pengawasan dari dinas terkait } \\
\hline Daya beli masyarakat menurun & & & & & & \\
\hline
\end{tabular}

Total TAS $* * *$

Keterangan :

*) Strategi Alternatif

**) Atractive Score

***) Total Attractive Score

\section{HASIL DAN PEMBAHASAN}

\section{Keadaan Umum PT Agro Lestari Merbabu}

PT Agro Lestari Merbabu merupakan perusahaan yang bergerak di bidang pertanian dengan komoditas kentang sebagai produk utama yang dibudidayakan. Produk lain yang dijual PT Agro Lestari Merbabu berupa cabai, kubis, seledri, daun bawang, sapi potong, bibit kentang dan keripik kentang. Kegiatan usaha budidaya dan jual beli kentang telah dimulai sejak Tahun 2016 dan pada Tahun 2018 berhasil mendapatkan perijinan penangkaran bibit kentang dari pihak BPSB (Badan Pengawasan dan Sertifikasi Benih) secara mandiri. Bibit hasil penangkaran digunakan untuk memenuhi kebutuhan saprodi perusahaan sendiri. Bibit yang ditanam mempunyai pengaruh sangat besar terhadap hasil yang didapatkan dan dapat memakan biaya sampai dengan $35 \%$ dari total biaya produksi. Kegiatan penangkaran benih dilakukan di screen house milik PT Agro Lestari Merbabu sendiri sehingga faktor lingkungan yang mempengaruhi pertumbuhan dapat dikendalikan dengan baik.

PT Agro Lestari Merbabu pada awalnya berbentuk P4S (Pusat Pelatihan Pertanian Pedesaan Swadaya) dan akhirnya pada Tahun 2020 usaha ini berbentuk PT (Perseroan Terbatas). Luas lahan yang dikelola PT. Agro Lestari Merbabu mencapai 23 ha dengan pembagian lahan milik sendiri seluas 3 ha dan 20 ha adalah lahan mitra berupa petani kentang. Produksi kentang setiap periode tanam (3 bulan) dapat mencapai 25 ton/ha. PT Agro Lestari Merbabu produk dan ukuran produk yang nantinya dipasarkan. PT Agro Lestari Merbabu mampu menghasilkan produk kentang yang berkualitas unggul karena didukung oleh lokasi yang strategis dan kondisi iklim.

Seiring berjalannya waktu, usaha ini semakin memperluas jangkauannya mulai dari berbagai komoditas mentah sampai produk pasca panen. Produk mentah perusahaan ini kebanyakan dipasarkan ke wilayah Kota Semarang dan Kabupaten Pekalongan. Produk olahan seperti keripik kentang yang dinamakan "Keripik Kentang Merbabu" diproduksi dalam skala yang tidak terlalu besar dan dipasarkan dengan sistem word of mouth. Produk dipasarkan pada wilayah yang masih terbatas yaitu disekitar Kabupaten Magelang dan Kota Solo. Kegiatan produksi keripik melibatkan komponen lain diluar PT Agro Lestari Merbabu yaitu anggota karang taruna di Desa Sumberejo sehingga terjalin hubungan yang harmonis antara Direktur, tenaga kerja dan anggota karang taruna. Keripik Kentang Merbabu mulai diproduksi sejak Tahun 2020 dan masih terus berjalan sampai dengan Tahun 2021. Produk yang dihasilkan dalam satu periode produksi (3 hari sekali) mencapai 300 produk. Produk keripik kentang ini mempunyai 3 varian rasa yaitu original, pedas dan rumput laut. 


\section{Kentang}

Kentang merupakan tanaman semusim yang menjadi komoditas utama yang dibudidayakan oleh PT Agro Lestari Merbabu. Tanaman kentang dapat produktif dan menghasilkan panen maksimal pada jenis tanah ringan yang mengandung sedikit pasir dan kaya bahan organik. PT melakukan budidaya tanaman kentang di wilayah Kabupaten Magelang tepatnya di Kecamatan Ngablak. Kentang yang dibudidayakan oleh PT Agro Lestari Merbabu meliputi 2 jenis yakni Kentang Granola dan Kentang Atlantik. Perusahaan membedakan pasar 2 produk unggulan ini yaitu dengan memasarkan Kentang Granola di pasar dan ke konsumen secara langsung sedangkan untuk Kentang Atlantik dipasarkan dengan sistem kontrak di Perusahaan dan diproduksi sendiri menjadi keripik kentang. Spesifikasi kedua kentang ini diperjelas oleh Adiyoga et al. (2014) bahwa varietas Granola mempunyai spesifikasi yaitu dapat diolah dan dikonsumsi sebagai kentang sayur sedangkan untuk varietas Atlantik dikonsumsi dalam bentuk keripik sehingga dijual sebagai baku industri keripik kentang.

\section{Produksi Keripik Kentang}

Kegiatan produksi keripik kentang dilakukan oleh tenaga kerja perusahaan beserta beberapa anggota karang taruna Desa Sumberejo. Tujuan dari kegiatan produksi secara keseluruhan adalah untuk memenuhi kebutuhan konsumen, meningkatkan nilai tambah suatu komoditas, menyediakan barang setengah jadi untuk keperluan produksi lanjutan, meningkatkan kemakmuran masyarakat sekitar dan meningkatkan devisa negara. Kentang mentah mengalami penyusutan sebesar $70 \%$ setelah diolah menjadi keripik kentang. Penyusutan bobot ini dapat terjadi karena adanya pengurangan kadar air pada kentang setelah kentang digoreng dan dikeringkan. Senada dengan pendapat Asgar dan Rahayu (2014) bahwa penyusutan bobot kentang merupakan pengurangan kadar air dalam kentang yang terjadi setelah dilakukan proses penyimpanan dan pengolahan.

Tabel 3. Bahan Baku dan Hasil Produksi Keripik Kentang Merbabu Periode Bulan Maret 2021

\begin{tabular}{|c|c|c|}
\hline Minggu ke- & Bahan Baku & Keripik Kentang \\
\hline & \multicolumn{2}{|c|}{---- kg ---- } \\
\hline 1 & 193 & 57,9 \\
\hline 2 & 180 & 54 \\
\hline 3 & 227 & 68,1 \\
\hline 4 & 200 & 60 \\
\hline Total Produksi & 800 & 240 \\
\hline
\end{tabular}

Mengacu pada Tabel 3. pengolahan kentang menjadi Keripik Kentang Merbabu pada periode produksi bulan Maret 2021 cenderung fluktuatif dan mengalami penurunan. Kenaikan dan penurunan volume produksi keripik kentang PT Agro Lestari Merbabu disebabkan oleh berbagai faktor produksi seperti penyediaan bahan baku, tenaga kerja terlatih, ketersediaan peralatan dan modal sendiri yang memadai. Menurut Agatha dan Wulandar (2018) faktor yang dapat mempengaruhi proses produksi keripik kentang meliputi sumber daya manusia, sumber daya alam dan sumber daya modal. Tenaga kerja yang menangani kegiatan produksi Keripik Kentang Merbabu terdiri atas tenaga kerja internal perusahaan dan anggota karang taruna. Kegiatan usaha yang masih terbilang baru menjadi alasan belum terstrukturnya pembagian kerja di dalam kegiatan produksi Keripik Kentang Merbabu sehingga berakibat pada manajemen usaha yang belum terkoordinasi dengan baik. Hal ini sesuai pendapat ILO (2013) bahwa pembagian kerja yang terstruktur dalam kegiatan produksi dan manajemen usaha yang baik dapat mendorong pencapaian visi misi perusahaan. Tenaga kerja yang telah terlatih menjalankan proses produksi secara maksimal sesuai dengan jobdesk mereka.

\section{Produk Keripik Kentang}

Produk keripik kentang yang diproduksi PT Agro Lestari Merbabu berlabel "Keripik Kentang Merbabu" memiliki variasi rasa berupa rasa original, pedas dan rumput laut. Variasi rasa ini menjadi salah satu daya tarik bagi konsumen untuk membeli dan mencoba keripik ini. Menurut pendapat Aristio et al. (2019) bahwa diversifikasi produk memperhatikan kapasitas produksi, kualitas produk, kemasan dan selera masyarakat serta dilakukan dengan melakukan strategi produk berupa variasi rasa, kemasan dan ukuran produk meningkatkan volume pembelian konsumen. Kemasan yang digunakan untuk melindungi produk berupa kemasan standing pouch bening kemudian dikemas lagi didalam kemasan sekunder berupa kardus sehingga produk lebih aman ketika dilakukan proses pengiriman dan tepat waktu sampai di tempat tujuan.

Informasi yang tercantum pada kemasan Keripik Kentang Merbabu masih kurang lengkap karena hanya meliputi komposisi, berat bersih dan nama perusahaan tanpa mencantumkan alamat produsen, cara penyimpanan, saran penyajian, kode produksi dan tanggal kadaluwarsa serta sertifikasi berupa label halal MUI sehingga konsumen lebih mempercayai produk. Produk keripik kentang dipasarkan di wilayah Magelang dan Solo. Sistem penjualan produk dengan cara pre order, setor ke toko serta Word of Mouth (WOM). Kegiatan ini dilakukan mengingat belum adanya toko atau stand tetap dan perusahaan belum banyak melakukan promosi di media sosial. Wilayah produksi keripik ini berada di dekat tempat-tempat wisata sehingga sangat memungkinan bagi perusahaan untuk memasarkan produknya kesana namun hal ini belum dilakukan perusahaan secara maksimal. Perusahaan memerlukan perencanaan strategi seperti perencanaan produk dan pemasaran produk sehingga dapat meningkatkan volume penjualan. 


\section{Nilai Tambah (Added Value)}

Nilai tambah merupakan perhitungan selisih lebih antara nilai produk dengan nilai biaya input dan tidak termasuk upah tenaga kerja. Menurut pendapat Santosa (2017) nilai tambah (added value) adalah nilai produk yang bertambah tinggi dikarenakan telah melalui berbagai proses pengolahan, pengangkutan ataupun penyimpanan yang mempunyai tujuan tertentu didalam suatu kegiatan produksi.

Tabel 4. Perhitungan Nilai Tambah Keripik Kentang Merbabu

\begin{tabular}{lc}
\hline \hline Variabel & Nilai \\
\hline Output (kg) & 30 \\
Bahan Baku (kg) & 100 \\
Tenaga Kerja (HOK) & 15 \\
Faktor Konversi & 0,3 \\
Koefisien Tenaga Kerja (HOK/Kg) & 0,15 \\
Harga Output (Rp/Kg) & 130.000 \\
Upah Tenaga Kerja (Rp/HOK) & 60.000 \\
Harga Bahan Baku (Rp/Kg) & 8.000 \\
Sumbangan Input Lain (Rp/Kg) & 10.467 \\
Nilai Output (Rp) & 39.000 \\
a. Nilai Tambah (Rp/Kg) & 20.533 \\
b. Rasio Nilai Tambah $(\%)$ & 52,65 \\
a. Pendapatan Tenaga Kerja (Rp/Kg) & 9.000 \\
b. Bagian Tenaga Kerja (\%) & 43,83 \\
a. Keuntungan (Rp/Kg) & 11.533 \\
b. Tingkat Keuntungan $(\%)$ & 56,17 \\
\hline
\end{tabular}

Hasil perhitungan pada analisis nilai tambah di Tabel 4. menunjukkan nilai output untuk Keripik Kentang Merbabu sebesar Rp130.000/kg. Nilai output ini dialokasikan untuk bahan baku berupa Kentang Atlantik sebesar Rp 8.000/kg dan sumbangan input lain sebesar $10.467 / \mathrm{kg}$. Faktor konversi pada pengolahan keripik kentang adalah 0,3 artinya dari $1 \mathrm{~kg}$ kentang hanya menghasilkan $0,3 \mathrm{~kg}$ keripik kentang. Hal ini dapat terjadi karena adanya bagian dari bahan baku berupa kentang yang terbuang yaitu kulit kentang, dan bagian kentang yang sudah rusak serta adanya proses penggorengan yang mengakibatkan hilangnya kadar air pada kentang. Nilai tambah yang tercipta dari pengolahan Kentang Atlantik adalah sebesar Rp 20.533/kg atau $52,65 \%$ dari nilai output. Nilai ini merupakan nilai tambah olahan produk sebelum dikurangi dengan pendapatan tenaga kerja.

Usaha Keripik Kentang Merbabu dapat dikatakan dapat memberikan nilai tambah bagi perusahaan karena nilai tambahnya sebesar $\mathrm{Rp}$ $20.533 / \mathrm{kg}$ yang artinya telah mencapai angka $>0$. Menurut Salsabila et al. (2019) perusahaan yang telah melakukan penjualan suatu produk jadi dapat dikatakan telah memberikan nilai tambah jika diperoleh angka nilai tambah dari perhitungan yang > 0 dan perusahaan dikatakan tidak memberikan nilai tambah jika angka nilai tambah < 0 . Rasio nilai tambah dari pengolahan kentang ini adalah 52,65 \%.
Angka ini menunjukkan bahwa rasio produk Keripik Kentang Merbabu dapat dikategorikan tinggi karena nilainya $>40 \%$. Hal ini sesuai pendapat Mubarok et al. (2015) bahwa rasio nilai tambah perusahaan dapat dikategorikan menjadi 3 macam yaitu, berkategori rendah jika nilai rasio nilai tambahnya $<15 \%$, dikategorikan sedang jika nilainya $15-40 \%$ dan dikategorikan tinggi jika nilainya $>40 \%$. Berdasarkan analisis nilai tambah dapat disimpulkan bahwa nilai output $\mathrm{Rp} 20.533,-/ \mathrm{kg}$ terdapat $52,65 \%$ nilai tambah dari output kentang.

Distribusi nilai tambah kepada tenaga kerja usaha Keripik Kentang Merbabu menunjukkan angka sebesar Rp 9.000/kg dengan rasio 43,83\%. Besarnya proporsi bagian tenaga kerja usaha tidak mencerminkan besarnya perolehan tenaga kerja. Angka ini hanya menggambarkan perbandingan antara besarnya bagian pendapatan usaha dengan bagian pendapatan pemilik usaha. Besarnya rasio nilai tambah usaha Keripik Kentang Merbabu lebih besar dibandingkan rasio imbalan tenaga kerja atau $52,65 \%>43,83 \%$ sehingga usaha ini dapat dikategorikan lebih berperan meningkatkan pertumbuhan ekonomi usaha. Menurut pendapat dari Hasanah et al. (2015) jika rasio imbalan tenaga kerja terhadap rasio nilai tambah tinggi, maka agroindustri lebih berperan dalam memberikan pendapatan bagi pekerjanya, sehingga lebih berperan dalam mengatasi masalah pengangguran melalui pemerataan kesempatan kerja sedangkan jika rasio nilai tambah yang lebih tinggi maka agroindustri lebih berperan untuk meningkatkan pertumbuhan ekonomi agroindustri. Keuntungan diperoleh dengan mengurangkan nilai tambah dengan pendapatan tenaga kerja. Keuntungan yang diraih usaha Keripik Kentang Merbabu Rp 11.533/kg atau sebesar 56,17\% sehingga dapat diartikan bahwa setiap $1 \mathrm{~kg}$ kentang yang diproduksi menjadi keripik menghasilkan keuntungan sebesar Rp 11.533.

\section{Strategi Pengembangan Usaha}

Perumusan strategi pengembangan usaha ini mempertimbangkan faktor internal dan eksternal perusahaan. Manajemen ini dilakukan dengan melihat kekuatan dan peluang serta memperhatikan kelemahan dan ancaman perusahaan. Hal ini sesuai pendapat David (2004) yang menyatakan bahwa tindakan yang diambil dalam strategi pengembangan mempertimbangkan adanya faktor-faktor yang mempengaruhi usaha baik faktor internal berupa kekuatan dan kelemahan maupun eksternal berupa peluang dan ancaman. Pengambilan keputusan dalam strategi pengembangan dilakukan dengan menggunakan analisis SWOT (Strenghts Weakness Opportunity Threaths) dan analisis strategi teknik matriks QSP (Quantitative Strategic Planning). Menurut Prasnowo et al. (2017) tahapan pada penyusunan strategi pengembangan menggunakan analisis SWOT dan analisis strategi yang meliputi tahap pemasukan (input stage), tahap pencocokan (matching stage) dan tahap keputusan akhir. Tahap 
pemasukan berisi hasil perkalian bobot dan rating faktor internal dan eksternal pada matriks IFE (Internal Factor Evaluation) dan EFE (Eksternal Factor Evaluation). Analisis lingkungan internal perusahaan dilakukan dengan menggunakan matriks IFE.

Berdasarkan pendapat Selvia dan Djuwendah (2018) bahwa matriks IFE mempunyai tujuan untuk mengetahui seberapa besar peranan faktor internal yang terdapat pada suatu perusahaan. Matriks IFE dapat ditunjukkan pada Tabel 5 .

Tabel 5. menunjukkan bahwa terdapat sepuluh kekuatan dan kelemahan yang dimiliki usaha Keripik Kentang Merbabu. Kekuatan utama produk ditandai dengan nilai tertimbang yang terbesar yaitu pada proses produksi mudah dilakukan dengan nilai 0,236 sedangkan kelemahan utama ditandai dengan nilai tertimbang yang terkecil yaitu pada perusahaan yang tidak banyak melakukan promosi dengan nilai 0,053. Matriks IFE menjelaskan kekuatan serta kelemahan produk keripik kentang. Analisis lingkungan eksternal kegiatan produksi dilakukan dengan menggunakan matriks EFE. Menurut pendapat yang dikemukakan Sakina dan Tangkesalu (2018) matriks EFE berguna untuk mengetahui seberapa besar peranan faktor eksternal dalam memaksimalkan peluang yang ada dan mengatasi ancaman yang terdapat pada perusahaan. Matriks EFE produk dapat ditunjukkan pada Tabel 6 .
Berdasarkan hasil analisis pada matriks EFE di Tabel 6. dapat dilihat bahwa terdapat sepuluh peluang dan sepuluh ancaman pada faktor eksternal yang dihadapi oleh PT Agro Lestari Merbabu. Peluang utama keripik pada matriks EFE ada 2 macam yang ditandai dengan nilai tertimbang yang terbesar yaitu kondisi wilayah mendukung kegiatan produksi dan banyak tempat wisata disekitar lokasi produksi dengan nilai 0,290 sedangkan ancaman utama ditandai dengan nilai tertimbang yang terkecil yaitu pada pertumbuhan pasar yang lambat dengan nilai 0,041. Matriks EFE menjelaskan mengenai peluang dan ancaman yang dimiliki produk Keripik Kentang Merbabu serta hasil rating dan pembobotan yang diperoleh dengan menanyakan kepada responden.

Tahap pencocokan berisi matriks Internal Eksternal (IE) dan matriks SWOT. Matriks IE berfungsi untuk mengetahui posisi perusahaan dalam sel. Hal ini diperjelas oleh David (2009) yang menyatakan bahwa matriks IE terdiri dari dua dimensi, yaitu total skor matriks IFE pada sumbu horizontal dan matriks EFE pada sumbu vertikal dan dipertemukan ke dalam sel yang berisi 3 strategi dan 9 kotak. Matriks IE usaha Keripik Kentang Merbabu terdapat pada Ilustrasi 3.

\section{Tabel 5. Matriks IFE}

\begin{tabular}{lccc}
\hline \hline Kekuatan (Streght) & Bobot & Rating & Nilai Tertimbang \\
\hline Pengelolaan keuangan usaha dengan baik & 0,049 & 2,7 & 0,133 \\
Harga yang ditawarkan terjangkau & 0,058 & 3,2 & 0,187 \\
Perusahaan melakukan pencatatan secara rinci & 0,047 & 2,6 & 0,123 \\
Memiliki modal sendiri yang memadai & 0,049 & 2,7 & 0,133 \\
Hubungan pimpinan dan karyawan yang baik & 0,062 & 3,4 & 0,211 \\
Rasa produk yang enak & 0,053 & 2,9 & 0,153 \\
Perusahaan memiliki bahan baku utama sendiri & 0,062 & 3,4 & 0,211 \\
Peralatan sudah tersedia & 0,055 & 3,0 & 0,164 \\
Proses produksi mudah dilakukan & $\mathbf{0 , 0 6 6}$ & $\mathbf{3 , 6}$ & $\mathbf{0 , 2 3 6}$ \\
Harga produk stabil & 0,057 & 3,1 & 0,175 \\
\hline Kelemahan (Weakness) & $\mathrm{Bobot}$ & $\mathrm{Rating}$ & Nilai Tertimbang \\
\hline Keterbatasan tenaga kerja produksi & 0,038 & 2,1 & 0,080 \\
PT Agro Lestari Merbabu belum lama berdiri & 0,051 & 2,8 & 0,143 \\
Pembagian kerja karyawan belum terstruktur & 0,051 & 2,8 & 0,143 \\
Teknologi yang digunakan masih sederhana & 0,049 & 2,7 & 0,133 \\
Perusahaan tidak banyak promosi & $\mathbf{0 , 0 3 1}$ & $\mathbf{1 , 7}$ & $\mathbf{0 , 0 5 3}$ \\
Penjualan produk tidak berkala & 0,047 & 2,6 & 0,123 \\
Kemasan produk kurang lengkap informasinya & 0,035 & 1,9 & 0,066 \\
Manajemen perusahaan belum terkoordinasi dengan baik & 0,047 & 2,6 & 0,123 \\
Produk belum dipasarkan ke luar wilayah & 0,047 & 2,6 & 0,123 \\
Sistem penjualan perusahaan pre order & 0,044 & 2,4 & 0,105 \\
\hline Total IFE & $\mathbf{1}$ & $\mathbf{2 , 8 2 1}$ \\
\hline
\end{tabular}


Tabel 6. Matriks EFE

\begin{tabular}{lccc}
\hline \hline Peluang (Opportunity) & Bobot & Rating & Nilai Tertimbang \\
\hline Merk perusahaan sudah dikenal masyarakat & 0,047 & 2,6 & 0,122 \\
Pengiriman barang tepat waktu & 0,069 & 3,8 & 0,262 \\
Komunikasi dengan klien maupun konsumen berjalan baik & 0,063 & 3,5 & 0,222 \\
Penambahan tenaga kerja memungkinkan & 0,060 & 3,3 & 0,197 \\
Kepercayaan konsumen terhadap produk & 0,043 & 2,4 & 0,104 \\
Budaya membeli oleh-oleh & 0,034 & 1,9 & 0,065 \\
Kondisi wilayah mendukung kegiatan produksi & $\mathbf{0 , 0 7 2}$ & $\mathbf{4 , 0}$ & $\mathbf{0 , 2 9 0}$ \\
Semakin berkembangannya teknologi (internet) & 0,043 & 2,4 & 0,104 \\
Banyak wisata disekitar lokasi produksi & $\mathbf{0 , 0 7 2}$ & $\mathbf{4 , 0}$ & $\mathbf{0 , 2 9 0}$ \\
Anggapan masyarakat bahwa produk harganya murah dan & 0,047 & 2,6 & 0,122 \\
berkualitas & Bobot & Rating & Nilai Tertimbang \\
\hline Ancaman (Threat) & 0,049 & 2,7 & 0,132 \\
\hline Persaingan produk serupa & 0,047 & 2,6 & 0,122 \\
Upah tenaga kerja yang sedikit & 0,043 & 2,4 & 0,104 \\
Kenaikan harga bahan baku pendukung & 0,054 & 3,0 & 0,163 \\
Pesaing mempunyai brand produk serupa yang lebih luas & $\mathbf{0 , 0 2 7}$ & $\mathbf{1 , 5}$ & $\mathbf{0 , 0 4 1}$ \\
jangkauannya & 0,038 & 2,1 & 0,080 \\
Pertumbuhan pasar yang lambat & 0,056 & 3,1 & 0,174 \\
Kondisi dan situasi lingkungan (mis. pandemi Covid 19) & 0,045 & 2,5 & 0,113 \\
Pelanggan yang peka terhadap harga barang pesaing & 0,045 & 2,5 & 0,113 \\
Tenaga kerja yang kurang professional & 0,042 & 2,3 & 0,096 \\
Kurangnya bimtek dan pengawasan dari dinas & $\mathbf{1}$ & & $\mathbf{2 , 9 1 9}$ \\
Daya beli masyarakat menurun & & & \\
\hline Total EFE & &
\end{tabular}

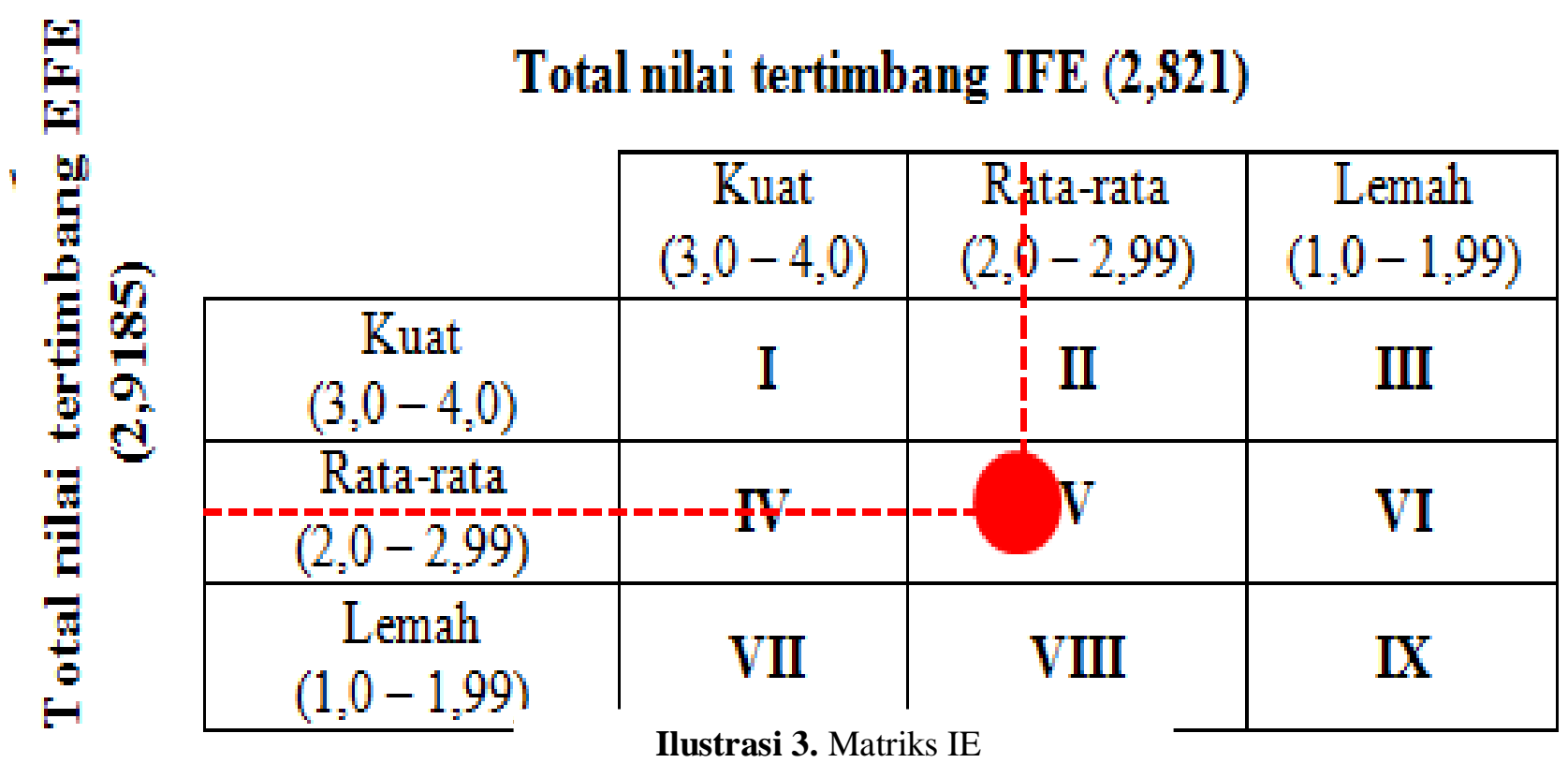

Ilustrasi 3. menggambarkan bahwa titik pertemuan total nilai tertimbang matriks IFE sebesar 2,821 dan total nilai tertimbang matriks EFE sebesar 2,918 posisi PT Agro Lestari Merbabu berada pada sel V. Titik ini menunjukkan bahwa faktor internal maupun eksternal yang dimiliki usaha Keripik Kentang Merbabu berada pada level rata-rata. Hal ini sesuai pendapat dari Naton et al. (2020) yang menjelaskan bahwa pada sel III, V, atau sel VII perusahaan lebih baik melakukan hold and maintain (pertahankan dan pelihara) dengan langkah melakukan penetrasi pasar, pengembangan produk dan pengembangan pasar. Faktor internal dan faktor eksternal dari usaha ini mendukung adanya pengembangan usaha.

Tahap pencocokan pada strategi pengembangan usaha diteruskan dengan menggunakan matriks SWOT. Matriks SWOT merupakan matriks yang bertujuan untuk menentukan alternatif pengambilan keputusan 
berdasarkan indikator kekuatan (strength), kelemahan (weakness), peluang (opportunity) dan ancaman (threats). Menurut pendapat yang dikemukakan Selvia dan Djuwendah (2018) matriks SWOT merupakan matriks berisi penentuan strategi yang ditempuh dengan memaksimalkan kekuatan dan peluang yang dimiliki namun secara bersamaan dapat meminimalkan kelemahan dan ancaman. Matriks SWOT dirumuskan berdasarkan pertemuan masing-masing indikator pada SWOT dan akan disesuikan dengan kebutuhan perusahaan.

EKSTERNAL
Peluang (Opportunity)
1. Merk PT dikenal masyarakat (O1)
2. Pengiriman barang tepat waktu (O2)
3. Komunikasi dengan konsumen baik (O3)
4. Penambahan tenaga kerja memungkinkan
(O4)
5. Kepercayaan konsumen terhadap produk
(O5)
6. Budaya membeli oleh-oleh (O6)
7. Kondisi wilayah mendukung (O7)
8. Berkembangannya teknologi (internet)
(O8)
10. Anggapan bahwa produk berkualitas (O10)

\section{Ancaman (Threats)}

11. Persaingan produk serupa (T1)

12. Upah tenaga kerja yang sedikit (T2)

13. Kenaikan harga bahan pendukung (T3)

14. Bahan baku utama berpatokan musim (T4)

15. Pertumbuhan pasar yang lambat (T5)

16. Kondisi dan situasi lingkungan (mis. pandemi Covid 19) (T6)

17. Pelanggan peka pada harga barang pesaing (T7)

18. Tenaga kerja kurang profesional (T8)

19. Kurangnya bimbingan teknis dan pengawasan dari dinas terkait (T9)

20. Daya beli masyarakat menurun (T10)

\section{Kekuatan (Strength)}

1. Perusahaan mengelola keuangan usaha dengan baik (S1)

2. Harga yang terjangkau (S2)

3. Pencatatan usaha secara rinci (S3)

4. Modal sendiri yang memadai (S4)

5. Hubungan direktur dan karyawan baik (S5)

6. Rasa produk yang enak (S6)

7. Perusahaan mempunyai bahan baku utama produksi sendiri (S7)

8. Peralatan sudah tersedia (S8)

9. Produksi mudah dilakukan (S9)

10. Harga produk stabil (S10)

\section{Strategi S-O (Strength Opportunity)}

- Meningkatkan kuantitas produksi dengan menyerap tenaga kerja lebih banyak (Strategi 1)

- Memasarkan produk ke tempat-tempat wisata di sekitar lokasi produksi dengan penawaran harga yang relatif terjangkau dan stabil (Strategi 2)

- Memanfaatkan modal seefektif mungkin untuk keberjalanan dan pengembangan usaha (Strategi 3)

- Mempertahankan hubungan antara pihak produsen ke konsumen maupun pihak didalam internal perusahaan (Strategi 4)

\section{Strategi S-T (Strength Threats)}

- Melakukan diversifikasi produk sehingga produk mempunyai ciri khas yang membedakan dengan produk lain

\section{Ilustrasi 3. Matriks SWOT} iviulanunan manajullus sun vallan baku utama produksi (Strategi 6)

- Meningkatkan kinerja karyawan dengan memberikan insentif ketika target penjualan dapat tercapai (Strategi 7)

- Meningkatkan kualitas produk yang dipasarkan (Strategi 8)

\section{Kelemahan (Weakness)}

1. Keterbatasan tenaga kerja (W1)

2. PT belum lama berdiri (W2)

3. Jobdesk belum terstruktur (W3)

4. Teknologi masih sederhana (W4)

5. Kurang melakukan promosi (W5)

6. Penjualan tidak berkala (W6)

7. Kemasan kurang lengkap informasinya (W7)

8. Manajemen perusahaan belum terkoordinasi dengan baik (W8)

9. Produk belum dipasarkan ke luar wilayah perusahaan (W9)

10. Produk bukan makanan primer (W10)

Strategi W-O (Weakness Opportunity)

- Meningkatkan branding perusahaan agar produk dapat dikenal masyarakat luas (Strategi 9)

- Memperluas pemasaran dan promosi produk dengan memanfaatkan perkembangan teknologi yang ada (Strategi 10)

- Melakukan penambahan tenaga kerja dan pembagian kerja yang terstruktur (Strategi 11)

- Memanfaatkan teknologi untuk memperbaiki kemasan (Strategi 12)

\section{Strategi W-T (Weakness Threats)}

Memperbaiki manajemen produksi dengan memaksimalkan kegiatan produksi dan dilakukan secara berkala (Strategi 13)

- Meningkatkan minat konsumen dengan pemberian diskon bagi pembeli tetap dan pembelian jumlah banyak (Strategi 14)

- Melakukan sistem kontrak kerja kepada tenaga kerja dan memberikan upah yang sepadan (Strategi 15)

- Mengundang pihak dinas untuk memberikan bimbingan dan arahan terkait kelayakan produk yang akan dijual (Strategi 16) 
Berdasarkan matriks SWOT pada Ilustrasi 3., ada 16 alternatif strategi yang dapat digunakan untuk melakukan pengembangan usaha Keripik Kentang Merbabu. Alternatif strategi ini nanti digunakan untuk menanyakan ke pihak perusahaan seberapa berpengaruh antara alternatif strategi terhadap faktor kunci pada IFE dan EFE. Berdasarkan pendapat Fauzi et al. (2016) matriks SWOT digunakan untuk menformulasikan strategi dengan penggabungan faktor internal dan eksternal perusahaan. Alternatif strategis disusun untuk mengetahui strategi yang tepat diimplementasikan pada perusahaan dengan pertimbangan kekuatan dan peluang untuk mengatasi kelemahan dan ancaman yang dihadapi perusahaan. Menurut pendapat Indariawati et al. (2011) bahwa alternatif strategis yang tepat akan diimplementasikan pada perusahaan dengan memaksimalkan kekuatan
Alternatif strategi dibuat dalam jumlah yang banyak dan merata diseluruh perumusan strategi SO, WO, ST dan WT yaitu sebanyak 4 alternatif disetiap strategi sehingga perusahaan lebih leluasa menentukan pilihan dan memberikan skor pada masing-masing alternatif strategi serta dapat disesuikan dengan kapasitas perusahaan.

Tahap keputusan akhir berisi matriks QSP untuk mengevaluasi strategi perusahaan obyektif. Pembuatan matriks QSP didasarkan pada hasil evaluasi pada faktor internal maupun eksternal yang mempengaruhi strategi pengembangan. Menurut (Wardani dan Khoirudin, 2015) tahap akhir berupa matriks QSP digunakan untuk mengevaluasi strategi secara obyektif berdasarkan faktor internal-eksternal yang telah diidentifikasi pada tahap sebelumnya. Perumusan matriks QSP dapat ditunjukkan pada

Tabel 7. Hasil Matriks QSP Usaha Keripik Kentang Merbabu

\begin{tabular}{|c|c|c|}
\hline $\begin{array}{l}\text { Prioritas } \\
\text { Strategi }\end{array}$ & Strategi & Total nilai TAS \\
\hline I & $\begin{array}{l}\text { Memasarkan produk ke tempat-tempat wisata di sekitar lokasi produksi dengan } \\
\text { penawaran harga yang relatif terjangkau dan stabil }\end{array}$ & 6,231 \\
\hline II & Memanfaatkan modal seefektif mungkin untuk keberjalanan dan pengembangan usaha & 5,903 \\
\hline III & Meningkatkan kuantitas produksi dengan menyerap tenaga kerja lebih banyak & 5,821 \\
\hline IV & $\begin{array}{l}\text { Mempertahankan hubungan antara pihak produsen ke konsumen maupun pihak } \\
\text { didalam internal perusahaan }\end{array}$ & 5,754 \\
\hline V & $\begin{array}{l}\text { Meningkatkan minat konsumen dengan pemberian diskon bagi pembeli tetap dan } \\
\text { pembelian jumlah banyak }\end{array}$ & 5,752 \\
\hline
\end{tabular}

dan peluang untuk mengatasi kelemahan dan ancaman.

Berdasarkan matriks QSP menunjukkan bahwa terdapat 5 alternatif strategi yang dapat direkomendasikan kepada PT Agro Lestari Merbabu utamanya pada produksi Keripik Kentang Merbabu. Nilai ini menandakan seberapa besar alternatif strategi dapat dijadikan strategi penyelesaian permasalahan produksi dan penjualan Keripik Kentang Merbabu. Hal ini sesuai pendapat David (2004) yang menyatakan bahwa teknik matriks QSP (Quantitative Strategic Planning) memadukan tahap pertama sebagai gambaran objektif strategi dan tahap kedua sebagai evaluasi strategi sehinggga menghasilkan alternatif strategi spesifik untuk pengembangan produk perusahaan. Strategi dengan nilai TAS terbesar menjadi pilihan utama strategi prioritas sedangkan strategi dengan nilai TAS terkecil merupakan pilihan terakhir. Strategi yang dipertimbangkan dalam alternatif strategi pada matriks QSP didasarkan pada hasil matriks IE yang menyatakan bahwa perusahaan berada pada sel V dengan salah satu solusi yang diambil berupa strategi penetrasi pasar. Penetrasi pasar merupakan strategi yang menekankan pada pemasaran produk yang sekarang dijalankan dengan melalui pertimbangan bahwa telah dimilikinya
Tabel 7. keahlian dan keterampilan dalam pengoperasian pemasaran. Hal ini sesuai pendapat Assauri (2013) yang menyatakan bahwa kegiatan penetrasi pasar yang ditingkatkan adalah dengan melakukan penambahan saluran distribusi dan cabang perusahaan, serta mengubah dan meningkatkan program promosi. Berdasarkan tabel di atas dapat dijelaskan bahwa hasil analisis data primer dengan menggunakan matriks QSP terhadap pengembangan usaha Keripik Kentang Merbabu PT Agro Lestari Merbabu antara lain :

1. Hasil perolehan nilai TAS pada alternatif strategi I adalah 6,231 yang berarti alternatif strategi utama yang perlu dijalankan adalah memasarkan produk ke tempat-tempat wisata dengan penawaran harga yang relatif terjangkau dan stabil. Strategi ini bertujuan untuk memperluas pasar produk Keripik Kentang Merbabu sehingga produk ini lebih banyak dikenal oleh masyarakat maupun wisatawan mengingat produk yang dihasilkan merupakan produk lokal yang berpotensi untuk terus dikembangkan

2. Hasil perolehan nilai TAS pada alternatif strategi II adalah 5,903 yang berarti alternatif strategi yang perlu dijalankan adalah memanfaatkan modal seefektif mungkin untuk keberjalanan usaha dan pengembangan usaha. Modal yang digunakan untuk menjalankan usaha berasal dari 
pihak internal perusahaan dan beberapa alat produksi dari dana hibah Universitas Sebelas Maret. PT Agro Lestari Merbabu mempunyai modal dan sumber keuangan yang terjamin. Hal ini menjadi kekuatan karena PT Agro Lestari Merbabu memiliki peluang untuk melakukan pengembangan pasar.

3. Hasil perolehan nilai TAS pada alternatif strategi III adalah 5,821 yang berarti alternatif strategi yang perlu dijalankan adalah meningkatkan kuantitas produksi dengan menyerap tenaga kerja lebih banyak. Kegiatan produksi keripik pada saat ini masih terbatas mengingat pasar produk yang belum meluas dan karyawan yang masih sedikit. Kondisi wilayah desa Sumberejo mendukung kegiatan produksi dengan ketersediaan tenaga kerja dan bahan baku produksi sehingga sangat memungkinkan apabila kuantitas produksi ditambah dan jumlah karyawan juga ditambah untuk mengimbangi kegiatan proses produksi.

4. Hasil perolehan nilai TAS pada alternatif strategi IV adalah 5,754 yang berarti alternatif strategi yang perlu dijalankan adalah mempertahankan hubungan yang baik antara pihak produsen ke konsumen maupun pihak didalam internal perusahaan. Sumber daya manusia merupakan aspek yang perlu diperhatikan dengan karena kaitannya dengan kegiatan proses produksi sehingga tercapai kualitas dan kuantitas produk sesuai dengan keinginan pasar. Hubungan yang baik antar sumber daya manusia yang berkualitas berpengaruh terhadap cara kerja mereka dalam melakukan proses produksi.

5. Hasil perolehan nilai TAS pada alternatif strategi $\mathrm{V}$ adalah 5,752 yang berarti alternatif strategi yang perlu dijalankan adalah meningkatkan minat konsumen membeli dengan strategi penjualan berupa pemberian diskon atau potongan harga bagi pembeli tetap maupun dalam jumlah banyak. Penerapan strategi penjualan ini kaitannya dengan kemampuan produsen dalam menarik minat konsumen membeli dan kepercayaan konsumen terhadap produk.

\section{KESIMPULAN}

Berdasarkan hasil penelitian dapat disimpulkan bahwa nilai tambah yang diperoleh perusahaan dari produk Keripik Kentang Merbabu adalah sebesar Rp 20.533,- setiap kilogramnya. Keripik Kentang Merbabu dapat dikatakan dapat memberikan peningkatan nilai tambah bagi perusahaan karena nilai tambahnya yang mencapai angka $>0$. Rasio nilai tambah dari Keripik Kentang Merbabu adalah $52,65 \%$. Angka ini menunjukkan bahwa rasio PT Agro Lestari Merbabu dapat dikategorikan tinggi karena nilainya > 40\%. Faktor internal yang mempengaruhi pengembangan usaha Keripik
Kentang Merbabu meliputi 2 hal yaitu meliputi kekuatan dan kelemahan usaha. Kekuatan utama produk berdasarkan matriks IFE ditandai dengan nilai tertimbang yang terbesar yaitu pada proses produksi mudah dilakukan dengan nilai 0,236 sedangkan kelemahan utama produk ditandai dengan nilai tertimbang yang terkecil yaitu pada perusahaan yang tidak banyak melakukan promosi dengan nilai 0,053 . Faktor eksternal yang mempengaruhi pengembangan usaha Keripik Kentang Merbabu meliputi 2 hal yaitu peluang dan ancaman usaha. Peluang utama keripik pada matriks EFE ada 2 macam yang ditandai dengan nilai tertimbang yang terbesar yaitu kondisi wilayah mendukung kegiatan produksi dan banyak tempat wisata disekitar lokasi produksi dengan nilai 0,290 sedangkan ancaman utama ditandai dengan nilai tertimbang yang terkecil yaitu pada pertumbuhan pasar yang lambat dengan nilai 0,041. Prioritas strategi pengembangan usaha yang perlu dijalankan oleh PT Agro Lestari Merbabu pada produk Keripik Kentang Merbabu adalah memasarkan produk ke tempat-tempat wisata dengan penawaran harga yang relatif terjangkau dan stabil. Strategi ini bertujuan untuk memperluas pasar produk Keripik Kentang Merbabu sehingga produk ini lebih banyak dikenal oleh masyarakat maupun wisatawan karena merupakan produk lokal yang berpotensi untuk terus dikembangkan.

\section{UCAPAN TERIMA KASIH}

Ucapan terima kasih dipersembahkan kepada :

1. Dr. Ir. Titik Ekowati, M.Sc.

2. Dr. Ir. Mukson, M.S.

3. Bapak dan Ibu dosen Prodi Agribisnis

4. Serta semua rekan dan pihak atas bimbingan, arahan dan dukungan dalam keberjalanan penelitian ini

\section{DAFTAR PUSTAKA}

Adiyoga W., Suwandi, dan A. Kartasih. 2014. Sikap petani terhadap pilihan atribut benih dan varietas kentang. J. Hortikultura. 24 (1) : 76 84

Agatha, M. K. dan E. Wulandar. 2018. Analisis faktor-faktor yang mempengaruhi produksi kentang di Kelompok Tani Mitra Sawargi Desa Barusari Kecamatan Pasirwangi Kabupaten Garut. J. Ilmiah Mahasiswa Agroinfo Galuh. 4 (3) : $772-778$.

Aristio, A., A. Wijaya, D. Laudry, G. A. Tjiputra, I. Kristopher, K. Widjanarko, V. Tan dan L. Marchalina. 2019. Pendampingan usaha kecil dan menengah donat kentang dalam peningkatan efisiensi, produktivitas, dan 
pendapatan. J. Pemberdayaan Masyarakat. 1 (2) : $379-392$.

Asgar, A. dan S. T. Rahayu. 2014. Pengaruh suhu penyimpanan dan waktu pengkondisian untuk mempertahankan kualitas kentang kultivar Margahayu. J. Biologi. 13 (3) : 283 - 293.

Assauri, S. 2013. Strategi Manajemen. PT Rajagrafindo Persada, Depok.

Ayesha, I. D. Torani dan Amnilis. 2020. Penerapan metode Hayami dalam analisis nilai tambah ubikayu menjadi produk olahan pada usaha Keripik Balado 4 x 7 di Kota Padang. J. Penelitian Pengetahuan dan Pengembangan. 2 (2) : $99-107$.

Badan Pusat Statistik. 2016. Luas, Produksi dan Produktivitas Hortikultura Indonesia. Badan Pusat Statistik, Jakarta.

David, F R. 2004. Manajemen Strategis KonsepKonsep. PT. Indeks Kelompok Gramedia, Jakarta.

David, F. R. 2009. Strategic Management. Penerbit Salemba Empat, Jakarta.

Elvia, R. 2016. Analisis Nilai Tambah Ubikayu sebagai Bahan Baku Keripik Singkong pada Home Industry Pak Ali di Desa Ujong Tanjung Kecamatan Mereubo Kabupaten Aceh Barat. Fakultas Pertanian, Universitas Teuku Umar Meulaboh, Aceh Barat. (Skripsi).

Fauzi, D., L. M. Baga dan N. Tinaprilla. 2016. Strategi pengembangan Agribisnis kentang merah di Kabupaten Solok. J. Agribisnis dan Perencanaan Pembangunan Pedesaan. 2 (1) : $87-96$.

Hasanah, U., Mayshuri dan Djuwari. 2015. Analisis nilai tambah Agroindustri sale pisang di Kabupaten Kebumen. J. Ilmu Pertanian. 18 (3) : $141-149$.

Hayami Y., T. Kawagoe, Y. Morooka dan M. Siregar. 1987. Pemasaran dan Pengolahan Hasil Pertanian di Dataran Tinggi Jawa (Studi Kasus Desa Sunda). Pusat CPGRT, Bogor.

Indariawati, P., S. Raharja dan S. T. Soekarto. 2011. Kajian strategis pengembangan usaha industri Kripik Singkong perusahaan PT. Inti Sari Rasa di Bekasi. J. Manajemen. 6 (2) : 99 - 104.
International Labour Office. 2013. Manajemen Sumber Daya Manusia : Modul 4. Publikasi ILO, Jakarta.

Mubarok, A. A., A. Arsyad dan H. Miftah. 2015. Analisis nilai tambah dan margin pemasaran pisang menjadi olahan pisang. J. Pertanian. 6 (1) : $1-14$.

Naton, S., D. Radiansah dan H. Juniansyah. 2020. Analisis nilai tambah dan strategi pengembangan usaha pengolahan pisang pada UMKM Keripik Tiga Bujang di Kota Pontianak. J. Sosial Ekonomi Pertanian. 16 (2) : $135-148$.

Nurdina, M. R. Ardhiani, C. M. S. Handayani dan F. Asj'ari. 2021. Strategi pemberdayaan UMKM makanan berbasis kearifan lokal di masa Pandemi Covid-19 di Desa Slempit Kedamean Gresik. J. Pengabdian Masyarakat. 2 (1) : 43 51.

Prasidi, D. 2020. Analisis Nilai Tambah Kentang sebagai Bahan Baku Kripik Kentang Keju (Studi Kasus : UMKM Snack Buenda, Jln. Jawa Gg. Buntu I, Kecamatan Medan Helvetia, Kota Medan). Fakultas Pertanian, Universitas Muhammadiyah Sumatera Utara, Medan. (Skripsi)

Prasnowo, M. A., A. Khomaruddin dan K. Hidayat. 2017. Strategi pengembangan sentra industri kecil menengah produksi kerupuk. J. Teknika Pengetahuan dan Mesin. 1 (1) : 17 - 24.

Sakina, S. dan D. Tangkesalu. 2018. Strategi pengembangan usaha keripik pisang pada industri "Flamboyan" di Kelurahan Panau Kecamatan Tawaeli Kota Palu. J. Agrotebis. 6 (3) : $371-378$.

Salsabila, S., D. Haryono dan Y. A. 2019. Syarief. Analisis pendapatan dan nilai tambah agroindustri keripik pisang di Desa Sungai Langks Kecamatan Gedong Tataan Kabupaten Pesawaran. J. Ilmu-Ilmu Agribisnis. 7 (1) : 68 $-74$.

Santosa, R. 2017. Kelayakan finansial dan nilai tambah usaha agroindustri keripik ubi kayu di Kecamatan Saronggi Kabupaten Sumenep. J. Pertanian Cemara. 14 (1) : 21 - 34.

Selvia, M. dan E. Djuwendah. 2018. Strategi pengembangan kentang (Solanum tuberosum L.) pada Kelompok Tani Palintang Jaya, Desa Cipanjalu Kecamatan Cilengkrang, Kabupaten 
Bandung. J. Agribisnis dan Sosial Ekonomi Pertanian. 3 (2) : $548-560$.

Sugiyono. 2018. Metode Penelitian Pendidikan. Alfabeta, Bandung.

Wardani, I. dan M. H. Khoirudin. 2015. Perencanaan strategi pengembangan agroindustri Kripik Singkong Presto di Cassava Gedongan, Kelurahan Ledok, Salatiga. J. Agronomika. 10 (2) : $11-21$. 